morbidity survey and found that more deaths were assigned to chronic bronchitis and chronic obstructive airways disease than to asthma. ${ }^{28}$

For every patient with a diagnosis of chronic bronchitis we found another two unlabelled patients with similar symptoms, and for every patient with the diagnosis of asthma we found two or three with wheeze and no diagnosis. This proportion of undiagnosed asthma has also been shown in children..$^{29} 30$ Moreover, if the threshold for the diagnosis of asthma was lowered to include any patients who had suffered an episode of wheezing in the past 12 months then up to a third of this population would be eligible for the label of asthma. This large reservoir of patients suggests that substantial shifts in "asthmatic" patients' rates of using hospitals and general practitioners could easily result from changes in diagnostic fashion alone.

The apparent lack of criteria on which the diagnosis of chronic bronchitis can be distinguished from asthma in adults together with the shift away from the label of chronic bronchitis suggests that a diagnostic transfer from chronic bronchitis to asthma has occurred. The increasing morbidity and mortality that is attributed to chronic obstructive airways disease also suggests that a new diagnostic fashion is emerging. ${ }^{6}$ Until we have universally agreed clinical and epidemiological diagnoses for asthma, chronic bronchitis, and chronic obstructive airways disease we should be cautious in postulating changes in the epidemiology of respiratory disease only on the basis of trends in drug prescriptions and service utilisation statistics. ${ }^{31} 32$

We thank Drs Pollock, Forrester, and Terrell for access to their patients and the secretarial staff of the practice for organising the patients' visits. The terbutaline and Nebuhalers were provided by Astra Pharmaceuticals.

\footnotetext{
1 Anderson HR. Increase in hospitalisation for childhood asthma. Arch Dis Child 1978;53:295-300

2 Office of Population Censuses and Surveys, Royal College of General Practitioners, Department of Health and Social Security. Morbidity statistics from general practice. Third national study 1981-82. London: HMSO, 1986. (Series MB5 No 1.)

3 Burney PGJ. Asthma mortality in England and Wales: evidence for a further increase, 1974-84. Lancet 1986;ii:323-6.

4 Alderson M. Trends in morbidity and mortality from asthma. Population Trends 1987;49:18-23.
}

5 Department of Health and Social Security, Office of Population Censuses and Surveys. Hospital in-patient enquiry. London: HMSO, 1978-86. (Seric $\mathrm{MB} 4,2,3,5,7,10,12,14,16,18,21,23,25$

6 Office of Population Censuses and Surveys. Mortality statistics: cause. London HMSO, 1974-84. (Series DH2, No 1-12.)

Anderson HR. Is the prevalence of asthma changing? Arch Dis Child $1989 ; 64: 172-5$

8 Burrows B, Niden AH, Barclay WR, Kasik JE. Chronic obstructive lung disease. Clinical and physiological findings in 175 patients and their relationship to age and sex. Am Rev Respir Dis 1965;91:521.

9 Dodge R, Cline MG, Burrows B. Comparisons of asthma and chronic bronchitis diagnoses in a general adult population. Am Rev Respir Dis 1986:133:981-6.

10 Higgins ITT. Respiratory symptoms, bronchitis, and ventilatory capacity in random sample of an agricultural population. Br Med 7 1957;ii:1198-203.

11 Higgins ITT, Oldham PD, Cochrane AL, Gibson JC. Respiratory symptoms and pulmonary disability in an industrial town: survey of a random sample of the population. Br Med F 1956;i:904-9.

12 Higgins ITT, Cochrane AL. Chronic respiratory disease in a random sample of men and women in the Rhondda Fach in 1958. Br f Ind Med 1961;18:93.

13 Olsen HC, Gilson G. Respiratory symptoms, bronchitis and ventilator capacity in men. Br.Med f 1960;i:450.

14 College of General Practitioners, Respiratory Diseases Study Group. Chronic bronchitis in Great Britain. Br Med f 1961;ii:973-9.

15 Williams BT, Nicholl JP. Prevalence of hypoxaemic chronic obstructive lung disease with reference to long term therapy. Lancet 1985;ii:369-72.

16 Medical Research Council. Definition and classification of chronic bronchitis for clinical and epidemiological purposes. Lancet 1965;i:775-9.

17 Cotes JE. Lung function: assessment and application in medicine. Oxford: Blackwell Scientific, 1975 .

8 Office of Population Censuses and Survers. Classification of occupations. London: HMSO, 1980.

19 College Committee on Thoracic Medicine. Disabling chest disease: prevention and care. $\mathcal{F} R$ Coll Physicians Lond 1981;15:69-87.

20 Littlejohns P, Williams ES. Job loss and family morbidity. I R Coll Gen Pract 1986;36:176.

21 Office of Population Censuses and Surveys. General household survey 1985 London: HMSO, 1987. (Series GHS No 14.)

22 Holland WW, Reid DD. The urban factor in chronic bronchitis. Lancet $1965 ;$ i: $445-8$.

23 Peckham C, Butler N. A national study of asthma in childhood. 7 kipidemiol Community Health 1978;32:79-85.

24 Wardman AG, Binns V, Clayden AD, Cooke NJ. The diagnosis and treatment of adults with obstructive airways disease in general practice. $\mathrm{Br} \mathcal{J}$ Dis Chest $1986 ; 80: 19-26$.

25 Bucknall CE, Robertson C, 'Moran F, Stevenson RD. Differences in hospital asthma management. Lancet 1988; ; 748 -50.

26 Burr ML, St Leger ST, Bevan C, Merrett TG. A community survey of asthmatic characteristics. Thorax 1975;30:663-8.

27 Brown PJ, Greville HW, Finucane KE. Asthma and irreversible obstruction. Thorax 1984;39:131-6.

28 Markowe HLJ, Bulpitt CJ, Shipley MJ, Rose G, Crombie DL, Fleming DM. Prognosis in adult asthma: a national study. Br Med f 1987;295:949-52.

29 Anderson HR, Bailey PA, Ceoper JS, Palmer JC. Influence of morbidity, illness label, social, family and health service factors on drug treatment of childhood asthma. Lancet 1981;ii: 1030-2.

30 Speight ANP, Lee DA, Hey EN. Underdiagnosis and treatment of asthma in childhood. Br Med f 1983;286:1253-8.

31 Fleming DM, Crombie DL. Prevalence of asthma and hay fever in England and Wales. Br Med f 1987;294:279-83.

32 Hay IFC, Higenbottom TW. Has the management of asthma improved? Lancet 1987;ii:609-10.

(Accepted 22 March 1984
Department of Child

Health, Medical School, University of Newcastle upon Tyne, Newcastle upon Tyne NE2 4HH

$\mathrm{R}$ Skinner, MRCP, honorary research associate

A D J Pearson, MRCP, lecturer

in paediatric oncology

L Price, RSCN, research sister

K Cunningham, MRCP,

Leukaemia Research Fund

training fellow

A W Craft, FRCP, director of

paediatric oncology

Correspondence to:

Dr Skinner.

BrMed f 1989;298:1560-1

\section{Hypophosphataemic rickets after ifosfamide treatment in children}

\author{
R Skinner, A D J Pearson, L Price, \\ $\mathrm{K}$ Cunningham, A W Craft
}

Ifosfamide is being increasingly used to treat solid tumours in children. Adverse effects include nausea, vomiting, alopecia, myelosuppression, and haemorrhagic cystitis. Nephrotoxicity has been reported in adults, with both glomerular disease! and tubular damage, which led to Fanconi's syndrome in two patients. ${ }^{23}$ Studies in children, however, have not found any appreciable nephrotoxicity. ${ }^{+}$We describe three children with previously normal renal function and bone biochemistry who developed hypophosphataemic rickets due to urinary loss of phosphate after high dose ifosfamide treatment for malignancy.

\section{Case reports}

Case 1-A 23 month old boy with embryonal rhabdomyosarcoma of the prostate received local radiotherapy and chemotherapy over 18 months. The chemotherapy comprised ifosfamide (total dose $\left.177 \mathrm{~g} / \mathrm{m}^{2}\right)$, cisplatin $\left(90 \mathrm{mg} / \mathrm{m}^{2}\right.$ per course with mannitol and hydration, total dose $359 \mathrm{mg} / \mathrm{m}^{2}$ ), cyclophosphamide, vincristine, adriamycin, actinomycin $\mathrm{D}$, and etoposide. He remained well with no evidence of recurrence of the tumour, but nine months after chemotherapy ended he developed difficulty in walking due to knock knees. Radiographs of his knees showed signs of rickets and secondary hyperparathyroidism. Further investigations showed a low glomerular filtration rate and renal tubular damage, with an adult type Fanconi's syndrome, comprising hypokalaemia, phosphaturia, hypophosphataemia, glycosuria, acidosis, and impaired urinary acidification and concentration (table). Serum alkaline phosphatase activity was raised. After treatment with oral phosphate his serum phosphate concentration rose to normal and his gait improved.

Case 2-A 4 year old girl with embryonal rhabdomyosarcoma of the left middle ear received radiotherapy and chemotherapy consisting of ifosfamide (total dose $132 \mathrm{~g} / \mathrm{m}^{2}$ ), actinomycin $\mathrm{D}$, adriamycin, vincristine, and etoposide. After receiving ifosfamide for eight months $\left(108 \mathrm{~g} / \mathrm{m}^{2}\right)$ she developed a painful limp; investigation showed hypophosphataemia, phosphaturia, glycosuria, and raised serum alkaline 


\begin{tabular}{|c|c|c|c|c|c|c|c|c|}
\hline & $\begin{array}{c}\text { Plasma } \\
\text { phosphate } \\
(\mathrm{mmol} / \mathrm{l})\end{array}$ & $\begin{array}{c}\text { Plasma } \\
\text { alkaline } \\
\text { phosphatase } \\
\text { (U/1) }\end{array}$ & $\begin{array}{l}\text { Plasma } \\
\text { potassium } \\
(\mathrm{mmol} / \mathrm{l})\end{array}$ & $\begin{array}{l}\text { Plasma } \\
\text { calcium } \\
(\mathrm{mmol} / \mathrm{l})\end{array}$ & $\underset{(\mathrm{mmol} / \mathrm{l})}{\stackrel{\text { Plasma }}{\text { magnesium }}}$ & $\begin{array}{l}\text { Fractional } \\
\text { excretion of } \\
\text { phosphate } \\
\quad(\%)\end{array}$ & $\begin{array}{l}\text { Fractional } \\
\text { excretion of } \\
\text { glucose } \\
(\%)\end{array}$ & $\begin{array}{c}\text { Glomerular } \\
\text { filtration } \\
\text { rate† } \\
\left(\mathrm{ml} / \mathrm{min} / 1 \cdot 73 \mathrm{~m}^{2}\right)\end{array}$ \\
\hline $\begin{array}{l}\text { Case } 1 \ddagger \\
\text { Case } 2 \\
\text { Case } 3 \$ \\
\text { Approximate normal range }\end{array}$ & $\begin{array}{c}0 \cdot 39 \\
0 \cdot 49 \\
0 \cdot 34 \\
1 \cdot 00-1 \cdot 75\end{array}$ & $\begin{array}{c}475 \\
536 \\
439 \\
71-212\end{array}$ & $\begin{array}{c}2 \cdot 3 \\
3 \cdot 4 \\
2 \cdot 4 \\
3 \cdot 3 \cdot 4 \cdot 7\end{array}$ & $\begin{array}{c}2 \cdot 66 \\
2 \cdot 29 \\
2 \cdot 43 \\
2 \cdot 13-2 \cdot 62\end{array}$ & $\begin{array}{c}0 \cdot 71 \\
0 \cdot 87 \\
0 \cdot 96 \\
0 \cdot 7 \cdot 1 \cdot 0\end{array}$ & $\begin{array}{l}90 \cdot 7 \\
12 \cdot 2 \\
32 \cdot 6\end{array}$ & $\begin{array}{l}41 \cdot 6 \\
16 \cdot 1 \\
50 \cdot 3\end{array}$ & $\begin{array}{c}66 \\
162 \\
76 \\
89-165\end{array}$ \\
\hline
\end{tabular}

^Fractional excretion of a substance ( $\mathrm{s}$ ) in urine calculated by $\mathrm{U}_{\mathrm{s}} / \mathrm{P}_{\mathrm{s}} \times \mathrm{P}_{\mathrm{cr}} / \mathrm{U}_{\mathrm{cr}} \times 100$, where $\mathrm{U}=$ urine concentration, $\mathrm{P}=$ plasma concentration, $\mathrm{Cr}=$ creatinine

tGlomerular filtration rate measured by clearance of edetic acid labelled with chromium- 51

$\ddagger$ Plasma bicarbonate concentration $14.0 \mathrm{mmol} / 1$; urine $\mathrm{pH} 6 \cdot 1$; osmolality of early morning urine sample $329 \mathrm{mmol} / \mathrm{kg}$.

SOsmolality of random urine sample $275 \mathrm{mmol} / \mathrm{kg}$; plasma osmolality $283 \mathrm{mmol} / \mathrm{kg}$.

phosphatase activity (table). She continued to receive ifosfamide for a further three months, but the limp persisted and radiographs of her wrists and knees two months later showed signs of rickets.

Case 3-A 3 year old girl with a malignant epithelial schwannoma of the nose received ifosfamide (total dose $124 \mathrm{~g} / \mathrm{m}^{2}$ ), adriamycin, vincristine, and etoposide. Nine months after diagnosis she developed severe nephrogenic diabetes insipidus and the ifosfamide was stopped. She also had more generalised renal tubular damage, and investigation two months later showed phosphaturia, hypophosphataemia, hypokalaemia, glycosuria, and a diminished glomerular filtration rate; serum alkaline phosphatase activity was high (table). Four months later she developed a limp, and radiographs of her wrists and knees confirmed rickets.

Other cases-Investigation of renal function in a further 10 children receiving high dose ifosfamide showed hypophosphataemia in two and considerable phosphaturia in three.

\section{Comment}

The three children described developed symptoms and radiological features of rickets with hypophosphataemia despite a normal plasma calcium concentration. The low plasma phosphate concentrations were due to renal tubular damage that resulted in phosphaturia. All were treated with oral phosphate supplements. The two adults previously reported with Fanconi's syndrome after chemotherapy with ifosfamide both had pronounced hypophosphataemia..$^{23}$ In contrast, the renal tubular damage caused by cisplatin leads to hypomagnesaemia, which was not present in our patients.

The renal tubular problems in our three children were probably caused by ifosfamide. The children all received $9 \mathrm{~g} / \mathrm{m}^{2}$ per course, given by continuous infusion over three days with mesna and hydration of $3 \mathrm{l} / \mathrm{m}^{2} /$ day. This dose schedule has not been widely used elsewhere but is included in the current study of Ewing's tumour by the United Kingdom Children's Cancer Study Group. The short term toxicity of this regimen is tolerable, ${ }^{5}$ but this is the first report of long term toxicity.

Hypophosphataemia causes muscle weakness, and rickets develops over several months. These cases and the pronounced phosphaturia found in a further three of 10 children receiving high dose ifosfamide treatment suggest that up to $45 \%$ of children receiving this treatment are at risk of developing rickets. Plasma phosphate concentrations should be measured regularly in all such children and phosphate supplements given if hypophosphataemia develops. Further follow up will determine whether the renal damage is reversible.

We thank the North of England Children's Cancer Research Fund, the Leukaemia Research Fund, and the special trustees of Newcastle Health Authority for financial help.

1 Van Dyk JJ, Falkson HC, van der Merve AM, Falkson G. Unexpected toxicity in patients treated with iphosphamide. Cancer Res 1972;32:921-4.

2 De Fronzo RA, Abeloff M, Braine H, Humphrey RL, Davis PJ. Renal dysfunction after treatment with isophosphamide (NSC-109724). Cancer Chemother Rep 1974;58:375-82.

3 Sangster G, Kaye SB, Calman KC, Dalton JF. Failure of 2-mercaptoethane sulphonate sodium (mesna) to protect against ifosfamide nephrotoxicity. Eur 7 Cancer Clin Oncol 1984;20:435-6.

4 Pinkerton CR. Rogers H, James C, et al. A phase II study of ifosfamide in children with recurrent solid tumours. Cancer Chemother Pharmacol 1985; 15 258-62.

5 Davies SM, Pearson ADJ, Craft AW. Toxicity of high dose ifosfamide in children. Cancer Chemother Pharmacol (in press).

(Accepted 12 April 1989)
Department of Obstetrics and Gynaecology and Laboratory of Fetal Physioloy, Università Cattolica S Cuore, Rome, Italy

Domenico Arduini, MD, deputy director of perinatal medicine centre Giuseppe Rizzo, MD, assistant

Salvatore Mancuso, MD, professor and chairman of department

Department of Obstetrics and Gynaecology,

Università di Ancona, Italy Carlo Romanini, MD, professor and chairman of department

Br Med f 1989;298:1561-2
Fetal haemodynamic response to acute maternal hyperoxygenation as predictor of fetal distress in intrauterine growth retardation

\author{
Domenico Arduini, Giuseppe Rizzo, Carlo \\ Romanini, Salvatore Mancuso
}

Doppler ultrasound has confirmed the redistribution of blood flow that occurs secondary to chronic hypoxia (the so called brain sparing effect) in fetuses with intrauterine growth retardation. ${ }^{1}$ We recently found that acute transmaternal treatment with oxygen induced pronounced haemodynamic modifications in these fetuses with temporary return of blood flow velocity waveforms towards normal. ${ }^{2}$ This paper reports an investigation assessing the diagnostic value, if any, of the fetal vascular response to transmaternal oxygen as a method of grading fetoplacental compromise in fetuses with retarded growth.

\section{Patients, methods, and results}

After getting informed consent we studied 22 fetuses fulfilling the following criteria: $(a)$ ultrasonic evidence of abdominal circumference below the fifth centile; ${ }^{3}(b)$ no evidence of congenital abnormality; (c) Doppler velocity waveforms in umbilical artery, descending thoracic aorta, and internal carotid artery abnormal (below the 10th and above the 90th centiles) compared with our reference ranges (see figure); (d) reactive cardiotocograms at the time of Doppler measurements.

Fetal blood flow velocity waveforms were recorded from the umbilical artery, descending aorta, and internal carotid artery by means of a commercially available pulsed Doppler system (Ansaldo Esacord 80 ). Waveforms were obtained as described $^{2}$ and 